\title{
Rural Tourism in the Perspective of Tourism Law (Case Study in Rural Tourism Cibalung Happyland Bogor)
}

\author{
Ida Nurhayati ${ }^{1}$, Abdillah $^{1}$, Vidaniar Yuristamanda Putri ${ }^{2}$ \\ \{ida.nurhayati@akuntansi.pnj.ac.id, abdillahpnj@gmai.com, vinda24@gmail.com\} \\ Department Accounting, State Polytechnic Jakarta ${ }^{1}$ \\ Department Finance and Banking, Vocational Program Universitas Indonesia ${ }^{2}$
}

\begin{abstract}
This study aims to explain how far rural tourism becomes the tourism industry as one of the special attractions by highlighting the uniqueness of each region. The government through its regulations, especially in efforts to develop the potential of villages especially in the field of tourism. Regional Autonomy Policy can encourage the growth and development of the tourism sector in the regions. Other government policies also encourage regional tourism, with the phenomenon of rural, natural and environment-based tourism. This study uses a descriptive qualitative method with formal, sociological and cultural juridical analysis. Using a case study in the rural natural attractions of Cibalung Happyland in Bogor, as one of the natural attractions that are rural. The existence of a tent camping area and agribusiness tourism complements the tourist attractions. The results of the study show that a large part of the visitor community now needs an unspoiled rural atmosphere. A comfortable atmosphere surrounded by a natural environment that is still green, fresh air, with quite simple facilities. This condition has been harmonized with the Tourism Act as a legal umbrella for the tourists and tourism industry entrepreneurs. Important for the future, the need for strong legal protection to tourists from matters related to safety, comfort in travel.
\end{abstract}

Keywords: natural tourism, legal protection, tourist

\section{Introduction}

In this era of openness, humans are not only physical needs such as food, clothing and shelter, but needs that are spiritual in nature, or non-physical, such as the need for security, comfort, peace of life in society. This situation shows that the needs as a human being become normal both physically and mentally. Steps to be able to meet these needs, among others, by traveling to places that can be happy and can create spiritual pleasure for humans.

Multilateral international tourism law regulations are carried out, first of all, in the United Nations system, which is tasked with adjusting international cooperation in solving problems that lead to the unique characteristics of economic, social, cultural and humanitarian conditions. [1]

One of the nature-based tourism objects in the area of Bogor Regency, West Java is Cibalung Happyland. The location is as follows: 


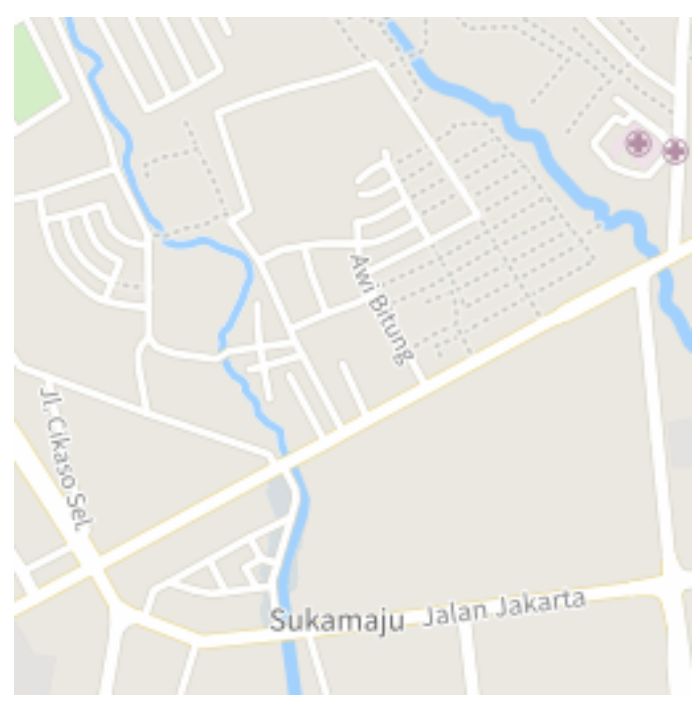

Figure 1. Cibalung Happy Land Location Map

Several rides are available there, including Agrokids, Agropark, Funkids, Meeting, Rafting, Funfam, Meeting, Waterpark, Outbound, etc. The vehicle there are some containing risks that need attention for safety in addition to comfort. Related to the safety of visitors, they are protected by the existence of Standard Operating Procedures on each vehicle, especially those at risk of accidents [13].

Government of the Republic of Indonesia through Undang-Undang No. 10 Tahun 2009 [2].Concerning Tourism, in the preamble stated that tourism plays an important role to expand and equalize business opportunities and employment, encourage regional development, increase national income in order to improve the welfare and prosperity of the people and foster the love of the motherland, enrich national culture and strengthen its development in order to strengthen identity nation and strengthen friendship between nations

The provisions illustrate that the tourism industry can also have an impact on various fields related to economic issues, including security.

This article explains the importance of protecting and maintaining the safety of visitors to the Cibalung Happy Land tourism object.

The protection includes security in the form of games, especially those that are vulnerable to accidents, such as Rafting, Waterpark, and Outbound. The game requires a representative safety device, even if there is need for protection in the form of insurance for visitors.

\section{Literature Review}

The development of a tourism village is making a new direction for the development of tourism in Indonesia.

\section{A. Rural Nature Tourism}

In the modern era like now, in general the community has understood the natural beauty of the village, which is still relatively dependent on the natural environment, beauty with fresh 
and natural shades of green, both from the lives of the people, the natural environment, as well as the traditions of the people who are unique in each region. The beauty of nature and the richness of nature and culture of Indonesia [10].

The concept of rural tourism (rural tourism) with its unique, distinctive product that reflects the natural conditions, society, and social culture. The shift in tourist interest towards the countryside in Indonesia is growing new tourism options in the form of tourist villages in various provinces in Indonesia.

Understanding of the tourism village is quite diverse, among others, saying that it is a form of residential environment that has special characteristics both natural and cultural in accordance with the demands of tourists where they can enjoy, recognize, appreciate and learn about the uniqueness of the village and all its attractions. Often tourists live in or close to the traditional atmosphere and learn about village life and the local environment, so there is a learning process from the community (hosts) to tourists (guests), so that guests are able to reward (rewarding) the values local that is still held by the local community [11].

Tourists who come to the tourist village will be able to enjoy the nature of the countryside that is still clean and feel life in a village atmosphere with a number of customs. Tourists stay with residents, sleep in a simple but clean and healthy room, traditional food is the main dish to be served while in the tourist village, tourists feel the satisfaction of being welcomed, and the services of the villagers [12].

In addition to being supported by the facts above, the current trend of tourists is more rational and has the character that tourist satisfaction is not only based on modern tourism facilities but also on the freedom and intensity of interaction with the environment and local communities. Based on this, the development of a tourist village has made a new direction for the development of tourism in Indonesia. The purpose of this study is to identify and recognize the potential of a village to become a tourist village [3].

Suwantoro, (1997) states that tourism is a process of traveling from one place to another which is temporary and outside of his residence, both individuals and groups. Tourism is held because of various interests such as cultural, social, religious or other interests with the aim of gaining pleasure, as well as fulfilling the desire to know something. Meanwhile, a person or group who travels is called a tourist if the length of stay is at least 24 hours in the area or tourist destination but if the length of stay is less than 24 hours is called a traveller [4]

\section{B. Tourist Legal Protection}

According to Law No. 10 of 2009 concerning tourism, tourism is a travel activity carried out by a person or group of people by visiting a particular place for recreational purposes, personal development or to learn the uniqueness of the tourist attraction visited in a temporary period. While tourism. While tourism is a variety of tourism activities and is supported by the community, entrepreneurs, government and local governments. The Government and Regional Governments have obligations in the development of tourism.

Provisions in Law No. 10 of 2009 listed:

(a) Provide tourism, legal protection, and security and safety information to tourists;

(b) Creating a climate conducive to the development of tourism businesses which includes opening up equal opportunities in trying, facilitating and providing legal certainty;

(c) Maintain, develop and preserve national assets that are a tourist attraction and potential assets that have not yet been excavated; and

(d) Supervise and control tourism activities in the context of preventing and overcoming various negative impacts on the wider community [5]. 
Ife (2014) referred by Rahmi (2016) The development of rural tourism is a concentration of the Indonesian government, related to cultural diversity, customs and natural beauty that is able to attract tourists both domestic and foreign. This diversity makes an extraordinary attraction that needs to be preserved, in order to preserve the natural beauty of Indonesia. In line with this, the presence of tourists is very important to be protected, both in terms of safety and comfort. The principles to emphasize are that cultural diversity needs to be maintained. Therefore, culture provides people with an identity and sense of belonging so that cultural development becomes very important for the community [6].

\section{METHOD}

This study uses a qualitative descriptive method with sociological, formal and practical juridical and analytical approaches and analysis. Xiong, et al (2019) researching based on a questionnaire survey of those rural tourism entrepreneurs who have set up business in the two townships of Huanglongxi and Luodai, and drawing upon social practice theory, the study explores concepts of entrepreneurship, organizational innovation, and sustainable competitive advantage. It shows how the entrepreneurship of the in- migration creative class has played a crucial role in organizational innovation in the tourism industry and how they have made significant contributions to sustainable competitive advantage [7].

Secondary data was taken from Cibalung Happyland about the types of rides / games and the number of visitors. Primary data is taken by conducting interviews with management, especially operational management, to get an explanation of the safety, comfort, and protection of tourists on each vehicle, especially those at risk of accidents in the use of the game.The data acquisition is analyzed using normative and implementation juridical analysis of the Tourism Act, especially in the section on safety and protection for tourists [10].

\section{RESULTS AND DISCUSSION}

\section{Legal Protection For Tourist}

Indonesia as a state based on Pancasila is obliged to provide legal protection to its citizens in accordance with what is stated in the Preamble of the 1945 Constitution 4th paragraph.[8]. Legal protection is also concentrated on tourists, which are regulated in Government Regulation of the President of the Republic of Indonesia Number 67 Concerning the Implementation of Tourism in its Considerations stated that in organizing tourism that utilizes the potential of national tourism, various efforts and steps are needed to continue strengthening the national identity, paying attention to quality and sustainability environment, tourist security, community participation and the sustainability of tourism businesses.[9] 
Table 1. Provisions Related to Legal Protection of Travelers

\begin{tabular}{|c|c|c|}
\hline Article & Clause & Analysis \\
\hline 44 & $\begin{array}{l}\text { 1) They provide the commercial nature of } \\
\text { tourist objects and attractions shall: provide } \\
\text { safety and security facilities and facilities;b. } \\
\text { maintain the sustainability of tourism objects } \\
\text { and attractions and their environmental } \\
\text { management. } \\
\text { (2) The operator of the exploitation of } \\
\text { natural tourist objects and attractions is } \\
\text { responsible for the safety and security of } \\
\text { tourists visiting the relevant natural tourist } \\
\text { objects and attractions }\end{array}$ & $\begin{array}{l}\text { a) This provision intends to } \\
\text { provide protection for the } \\
\text { safety and legal protection of } \\
\text { tourists } \\
\text { b) Maintain and protect the } \\
\text { natural environment of } \\
\text { attractions }\end{array}$ \\
\hline 45 & $\begin{array}{l}\text { The management of natural tourist objects } \\
\text { and attractions in the form of National Parks, } \\
\text { Nature Tourism Parks, Grand Forest Parks, } \\
\text { or Marine Parks, shall be carried out with } \\
\text { due observance of applicable laws and } \\
\text { regulations }\end{array}$ & $\begin{array}{l}\text { This provision is aimed at } \\
\text { entrepreneurs of attractions } \\
\text { to comply with regulations } \\
\text { that have been determined by } \\
\text { the government }\end{array}$ \\
\hline
\end{tabular}

\section{Source: Processed, 2019}

The data above shows that there is still very little legal protection for the safety and security of tourists in tourism objects. In fact, one factor that can encourage tourists to visit tourist attractions legal protection from the government.

\section{Tourism Object Cibalung Happy Land Bogor}

Tourist attractions with the concept of nature, especially rural nature with its agrotourism vehicle. CHL as an alternative choice of a good tour domestic and foreign tourists. As a company engaged in the field of tourism services, CHL is very concerned about the safety, safety and comfort of the visitors. The data shows that the trend of tourist visits is quite good, stable by looking at the situation and economic conditions of the community in general [14].

The following is the data of the visitors of CIbalung Happy Land

Table 2. Visitor Data CV. Cibalung Happy Land

\begin{tabular}{|c|c|c|c|c|}
\hline Type of Game & $\mathbf{2 0 1 6}$ & $\mathbf{2 0 1 7}$ & $\mathbf{2 0 1 8}$ & $\mathbf{2 0 1 9}$ \\
\hline Entrance Ticket & 9.050 & 8.424 & 6.371 & 5.161 \\
\hline Flying Fox & 3.301 & 2.787 & 2.795 & 1.608 \\
\hline ATV Rider & 650 & 66 & 259 & 0 \\
\hline Bungee Trampolin & 512 & 710 & 386 & 399 \\
\hline $\begin{array}{c}\text { Perang } \\
\text { Bantal/pillow fight }\end{array}$ & 513 & 297 & 204 & 210 \\
\hline Paint Ball & 360 & 751 & 311 & 162 \\
\hline Rafting & 195 & 431 & 156 & 70 \\
\hline $\begin{array}{c}\text { Lukis Caping/caping } \\
\text { painting }\end{array}$ & 2.560 & 2.208 & 2.140 & 951 \\
\hline Waterpark & 32.303 & 37.386 & 16.686 & 24.862 \\
\hline
\end{tabular}

Source : Cibalung Happy Land, 2019 
The data above is still in the current year 2019 showing that, in general, all rides have decreased visitors. If you notice there are several factors causing: 1 . The number of competitors who provide the same vehicle;2. Tight competition between organizers;3. Less updated types of vehicles;4. Factors beyond the ability of humans (nature)These factors can be strived for its recovery and even improvement, by always responding to the wishes of the community by taking into account the growing trends in society.

In some rides, for example, Flying Fox, ATV Rides, Bungee Trampoline, Pillow War, Paint Ball, Rafting, and Waterpark, the cost of the ticket is already included in accident insurance. This shows that the company has protected CHL visitors. Likewise, in each vehicle, there are guiding officers who are responsible for the operation of the vehicle.

\section{CONCLUSION}

The development of rural tourism found in Cibalung Happy Land, as a form of participation to the government which is intensively socializing and promoting natural beauty, culture, customs, culinary, and others which are oriented to village life the Government of the Republic of Indonesia through the Tourism Act is more regulating to its companies. It is hoped that there will be more concrete legal protections for tourists. That is the need for synergy between the government, business people and the community in creating harmonious rural tourism.

\section{ACKNOWLEDGEMENTS}

The author thanks the Republic of Indonesia Ministry of Technology and Higher Education Risaet, Directors, Deputy Directors, and Chairperson of the Jakarta State Polytechnic Accounting Department for providing this research opportunity and funding.

\section{REFERENCE}

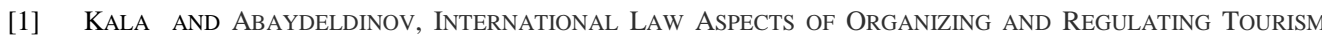
ACTivity Within the United Nations System. Journal of AdVANCED ReSEARCh In LAW AND ECONOMIC. Vol 7 No 8 (2016)

$[2,8]$ Undang-Undang Nomor 10 Tahun 2009 Tentang Kepariwisataan.

[3] Winarni dan Latianingsih. Potensi Desa Melalui Wisata Pedesaan. Jurnal Epigram. Vol. 11 No. 1 April 2014:6570

[4,6] Rahmi, A.S. Pembangunan Pariwisata Dalam Perspektif Kearifan Lokal. Reformasi-ISSN 2407-6864 Vol. 6, No. 1, 2016.

[5] op cit 2

[6] Ife, Jim \& Frank Tesoriero. 2008. Alternatif Pengembangan Masyarakat di Era Globalisasi Community Development. Yogyakarta: Pustaka Belajar. Nugroho, Riant. 2014. Kebijakan Sosial untuk Negara Berkembang. 
[7] Xiong, et al. The rural creative class: An analysis of in- migration tourism entrepreneurship. International of Tourism Research. 2019. Accessed September, 09,2019. At

https://onlinelibrary.wiley.com/doi/full/10.1002/jtr.2317\#accessDenialLayout

[9] Peraturan Pemerintah Presiden Republik Indonesia Nomor 67 Tentang Penyelenggaraan Kepariwisataan

[10] Melang, et al.. Strategi Pemerintah Daerah Dan Masyarakat Dalam Pengembangan Kampung Adat Tutubhada Sebagai Desa Wisata Di Kabupaten Nagekeo Provinsi Nusa Tenggara Timur. Jurnal Kepariwisataan Dan Hospitalitas. Vol. 3. No. 1. April 2019.

[11] Adawiyah, dkk. 2017. Strategi Pengembangan Desa Wisata Berbasis Masyarakat. (Community Bases Rural Tourism) Di Desa Papringan). Prosiding Seminar Nasional dan Call for Papers"Pengembangan Sumber Daya Perdesaan dan Kearifan Lok al Berkelanjutan VII" 17 - 18 November 2017 Purwokerto.

[12] Ethika, D.T, 2016. Pengembangan Pariwisata Berbasis Budaya Berdasarkan Undang-Undang Nomor 10 Tahun 2009 Di Kabupataen Sleman. Jurnal Kajian Hukum.Vol. 1. No. 2. (2016)

[13] Sarsiti dan Taufiq, M. Perlindungan Hukum Terhadap Wisatawan Yang Mengalami Kerugian Di Obyek Wisata (Studi Di Kabupaten Purbalingga). Jurnal Dinamika Hukum. Vol. 12. No. 1. Januari 2012

[14] Oktaviarni, F. 2018. Perlindungan Hukum Terhadap Wisatawan Menurut Undang-Undang Nomor 10 Tahun 2009 Tentang Kepariwisataan. Jurnal Wajah Hukum. Vol. 2. No. 2. Universitas Batanghari Jambi. 